\title{
Touraj Daryaee. « If these Walls Could Speak. The Barrier of Alexander, Wall of Darband and Other Defensive Moats »
}

\section{Rika Gyselen}

\section{(2) OpenEdition Journals}

Édition électronique

URL : http://journals.openedition.org/abstractairanica/42647

DOI : 10.4000/abstractairanica.42647

ISBN : 1961-960X

ISSN : 1961-960X

Éditeur :

CNRS (UMR 7528 Mondes iraniens et indiens), Éditions de l'IFRI

\section{Référence électronique}

Rika Gyselen, «Touraj Daryaee. «If these Walls Could Speak. The Barrier of Alexander, Wall of Darband and Other Defensive Moats » », Abstracta Iranica [En ligne], Volume 37-38-39 | 2018, document 19, mis en ligne le 10 mars 2018, consulté le 28 septembre 2020. URL : http://journals.openedition.org/ abstractairanica/42647 ; DOI : https://doi.org/10.4000/abstractairanica.42647

Ce document a été généré automatiquement le 28 septembre 2020

Tous droits réservés 


\title{
Touraj Daryaee. « If these Walls Could Speak. The Barrier of Alexander, Wall of Darband and Other Defensive Moats »
}

\author{
Rika Gyselen
}

\section{RÉFÉRENCE}

Touraj Daryaee. « If these Walls Could Speak. The Barrier of Alexander, Wall of Darband and Other Defensive Moats », in S. Pello, Orders. Itineraries on the Edges of Iran (Eurasiatica 5), 2016, p. 79-88.

1 Synthèse de nos connaissances à propos des murs de défenses renforcés par des forts que les Sassanides ont érigés à des endroits vulnérables de leurs frontières.

2 L'auteur commente quatre murs de défense : 1) celui du Gurgān (souvent citée comme 'la barrière d'Alexandre') qui part de la mer Caspienne à travers la steppe vers les montagnes à l'est sur quelque $190 \mathrm{~km}$ et qui date des Ve - VIe s., 2) celui de Tammishe qui va du coin sud-est de la mer Caspienne vers les contreforts de l'Elbourz et que la tradition littéraire attribue à Husraw Ier (sur ces deux murs voir Sauer et al. 2013, Persia's Imperial power in Late Antiquity), 3) le mur de Darband qui part de la mer Caspienne près de Darband vers l'ouest sur quelque $40 \mathrm{~km}$, dont la construction est ancienne et qui a été restauré aux V $\mathrm{V}^{\mathrm{e}}-\mathrm{VI}^{\mathrm{e}}$ siècles, et 4) le War-ī Tazìgān ou 'mur des arabes' qui contourne l'ouest de l'Euphrate à partir du Golfe Persique jusqu'au nord de la capitale sassanide et dont la construction remonte au IV siècle. 


\section{AUTEURS}

\section{RIKA GYSELEN}

CNRS, Mondes iranien et indien 